\title{
SPECIFIC BUSINESS CONTINUITY MANAGEMENT PRACTICES DURING THE COVID-19 PANDEMIC CRISIS
}

\author{
Diana Elena RANF \\ "Nicolae Bălcescu” Land Forces Academy, Sibiu, Romania \\ ranf.diana@armyacademy.ro \\ Gabriel MĂNESCU \\ "Nicolae Bălcescu” Land Forces Academy, Sibiu, Romania \\ manescu.gabriel@armyacademy.ro \\ Dorel BADEA \\ “Nicolae Bălcescu” Land Forces Academy, Sibiu, Romania \\ badea.dorel@armyacademy.ro
}

\begin{abstract}
The article contains an analysis of the concept of "business continuity management" in terms of literature in the field and how it can support organizations in times of pandemic crisis. The main objective of the article is to identify a correlation between the efforts of organizations to survive on the one hand and the main tools that can ensure business continuity in the context of the economic and health crisis caused by the Covid pandemic. Periods of crisis, regardless of their nature, economic, social, health have as a consequence of the changes they propagate in all systems of society, a reorganization and rethinking of the functioning of private or public organizations.
\end{abstract}

KEYWORDS: business continuity management, resilience, crisis, pandemic

\section{Introduction}

The article contains an overview of the main publications regarding the concept of business continuity management, respectively an evolution from a scientific and practical point of view. The purpose of approaching the concept is to identify the contribution it can make in providing solutions to overcome the difficulties encountered by organizations following health protection measures against the COVID-19 pandemic.

The sanitary protection measures adopted at national level had a negative impact on the private environment, not being doubled in due time by measures of economic protection of the private environment. Ensuring the resilience of the private system has come to depend on factors such as: managerial capacity, spare own funds, ability to reorganize the business, rapid response to change, flexibility and great adaptability to new needs in the market.

The concept is passed through the filter of practical applicability in different contexts, such as: natural disasters, economic crises, pandemics. The application by organizations of a business continuity management can considerably reduce the risk of failure or reduction of the activity in case of negative influences from the 
external environment. Resilience at the societal level is strongly influenced by the ability of organizations to respond effectively to emerging challenges.

\section{Evolution of the Business}

Continuity Management Concept

According to ISO 22301, published in 2012, the main intention of the business continuity management system is to anticipate as many of the potential disruptive scenarios that may affect organizational processes, to establish preventive actions and to implement processes that help the organization to recovers faster after a disruptive event (Herfried, 2020).

In the organizational context, business continuity management has evolved into a process that identifies an organization's exposure to internal and external threats and synthesizes strengths and weaknesses to focus on prevention and effective recovery after a period of crisis (Herbane, Elliott \& Swartz, 2004). The potential contribution of an organization is that of preserving value.

The concept of Business Continuity Management (BCM) can make a significant contribution to gaining a distinct competency with competitors in terms of organizational resilience, namely a rapid recovery of functions (activities) affected by different types of crises, minimizing the negative impact on the income and reputation of organizations (Bakar, Azbiya Yaacob \& Udin, 2015). The link between business continuity management and resilience is emphasized, especially in the context of increasing economic damage caused by global disasters and the recognition of the role of the private sector as a partner in disaster management. Retaining jobs and reducing the impact on the national, regional and global economy are among the objectives of developing business continuity plans (Baba, Watanabe, Nagaishi \& Matsumoto, 2014).
One of the conclusions of the research carried out on this topic states that a continuity of successful business is ensuring that the business model adopted by organizations is resistant to the influences of the external environment (Niemimaa, Järveläinen, Heikkilä \& Heikkilä, 2019).

The term BCM is mentioned as an organizational capability that can ensure resilience in a study that analyzed in Romania the premises necessary to build a management of business continuity and the conditions necessary to maintain it (Păunescu, Popescu \& Blid, 2018).

Regarding the application of the concept of BCM in the public sector, a study involving the interviewing of stakeholders from state institutions at local, sectoral or national level in Finland, identified a variation of practices in the field (Järveläinen, 2020). The results identified organizations with mature business continuity management practices, with highly involved management, regularly updated continuity and recovery plans for all systems, but also organizations within which a lack of knowledge and awareness of the importance of BCM among leadership, as well as partial or non-existent continuity plans.

However, small and medium-sized enterprises, especially in developing countries, although many of them are located in areas vulnerable to natural disasters (prone to earthquakes, floods, etc.), have not achieved a response plan to such risks, even more they have not implemented the standard of Business Continuity Management.

The dynamics of the changes that appeared in the context of the economic crisis also left their mark on the forms of employment, which are already constantly changing. To ensure business continuity, employers on the one hand and employees on the other hand need to adapt to these new requirements, which can economically 
restore organizations and also respond more effectively to labor market needs.

Eurofound, the European Union Agency for the Improvement of Living and Working Conditions, published in 2015 a study on changes in the labor market with regard to new forms of employment. Thus, the study presented nine forms of employment: ICT-based mobile work, platform work, casual work, employee sharing, job sharing, voucher based work, collaborative employment, interim management and portfolio working (Eurofound, 2015).

ICT-based mobile work: work outside the employer's or client's premises, with the support of modern technologies and without having the fixed character of telework (Mandl \& Curtarelli, 2017). The employee or self-employed person can carry out activities in different locations outside the headquarters of their employer, supported by modern technologies such as laptops and tablets (Bucovetchi, Stanciu, \& Pulfer, 2017).

The concept of Platform work was analyzed as an opportunity long before the pandemic imposed its rules on the labor market. Platform workers are people who use an application or a website to keep in touch with customers, to promote and sell their products/services (Organisation for Economic Cooperation and Development (OECD), 2019).

Another form of work practiced more or less in all parts of the world is called casual work and involves occasional forms of work, such as day work, occupations that tend to be less secure, less paid, and involve disadvantaged workers (Theodore, Schenck \& Blaauw, 2018).

Employee sharing is a new form of employment, defined in a 2015 Eurofound report on new forms of employment as a type of employment in which a group of employers hires joint workers and is jointly responsible for them. The concept was also analyzed in the context of new trends towards increased employment flexibility, with emphasis on the particular characteristics of employee sharing as a new flexible form of employment, with benefits for employees and employers, widely used in the context of globalization (Marica, 2020).

Job Sharing is an employment agreement in which two people are usually employed part-time or short-time to fulfill the responsibilities of a full-time position. Because all positions are shared, this leads to a net reduction in employee income.

Voucher based work is a kind of employment in which the employment relationship and the related payment are based on a voucher, not on an employment contract. In most cases, workers have a status somewhere between employees and the self-employed workers.

Collaborative employment refers to situations in which self-employed professionals and organizations cooperate to overcome certain situations characterized by emergencies or professional isolation (Eurofound, 2015).

Interim management is one of the tools that can help ensure business continuity in times of crisis, being defined as a temporary "provider" of resources and management skills by taking on short-term management responsibilities by a manager capable of managing a business period of transition, crisis or change within an organization (Şenturan \& Şermin, 2018).

The concept of working portfolio provides a solution for periods when the labor market is undergoing changes in terms of employers and employees, materialized by the disappearance of jobs and the development of new requirements in terms of skills needed for employment. Thus the concept of portfolio working, which is already embraced by the category of young people in developed countries involves adapting and flexibility of the workforce to change, gaining experience by practicing a large number of full-time or part-time jobs, which leads to the 
concept "career of a lifetime" becoming old-fashioned.

A study (Eurofound, 2020) on new forms of employment adopted at European level in 2020, in a context in which the labor market is already affected by changes caused by the economic and health crisis shows that few countries in the European Union practice all nine forms of employment.

Table no. 1

Forms of employment practiced by Romania compared to European Union countries

\begin{tabular}{|c|c|c|}
\hline FORMS OF EMPLOYMENT & $\begin{array}{c}\text { PRACTICED } \\
\text { IN ROMANIA }\end{array}$ & $\begin{array}{c}\text { COUNTRIES WHERE THE } \\
\text { FORM OF EMPLOYMENT } \\
\text { IS PRACTICED }\end{array}$ \\
\hline ICT-BASED MOBILE WORK & $\mathrm{x}$ & 27 out of 27 \\
\hline PLATFORM WORK & $\mathrm{x}$ & 26 out of 27 \\
\hline CASUAL WORK & $\mathrm{x}$ & 23 out of 27 \\
\hline EMPLOYEE SHARING & $\mathrm{x}$ & 16 out of 27 \\
\hline JOB SHARING & & 18 out of 27 \\
\hline VOUCHER BASED WORK & $\mathrm{x}$ & 9 out of 27 \\
\hline COLLABORATIVE EMPLOYMENT & & 25 out of 27 \\
\hline INTERIM MANAGEMENT & & 15 out of 27 \\
\hline PORTFOLIO WORKING & & 16 out of 27 \\
\hline
\end{tabular}

(Source: processing after Eurofound, 2020)

The current context of the crisis caused by the Covid-19 pandemic has challenged organizations to identify new forms of employment that comply with existing legislation, so as to ensure the sustainability of the business and avoid as much staff redundancy as possible.

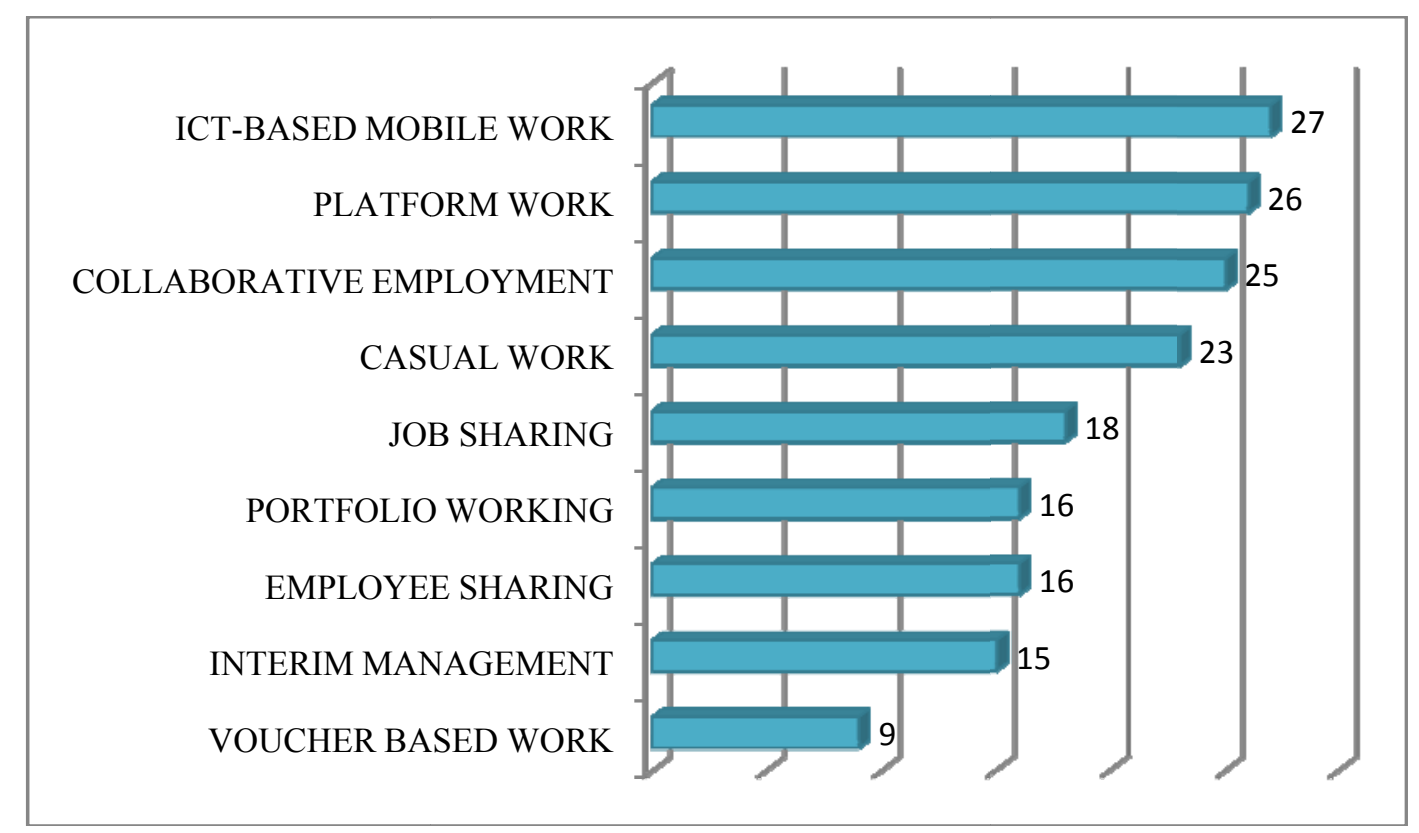

Figure no. 1: The most used new forms of employment at European level in the context of the Covid-19 pandemic

(Source: processing after Eurofound, 2020) 
Figure no. 1 shows a natural consequence of the health protection measures adopted by the authorities at European level, namely work at home with the support of technology (Bucoveţchi, 2013). Flexibility in carrying out activities, such as working on different platforms, without having a fixed location, have already been identified as opportunities, facilitating the current transition to the concept of telework. Implementing these changes is one of the measures recently adopted by private organizations to overcome the crisis and ensure business continuity.

\section{Measures Adopted by National Authorities for the Protection of the Private Environment}

The private environment in Romania suffered during the year 2020 as a result of the protection measures adopted by the authorities. Among the most affected areas are tourism, transport and hospitality and restaurants, although the decline has been in the chain affecting other industries.

In this context, the European Commission approved a 3.3 billion euro aid scheme for Romania, aimed at supporting small and medium-sized enterprises (SMEs) in the context of the COVID-19 pandemic (European Commission, 2020).

In summary, the main measures taken to ensure the survival of the private environment were:

1. Regulation of technical unemployment as being covered from the unemployment insurance budget, thus ensuring the protection of the population during the suspension of the activity of certain sectors.

2. Extending the use of work performed through information and communication technology regulated in Romania by Law no. 81/2018, and at the level of the European Union since 2002 (Zanfir, 2018).
3. Support for public loan guarantees, for example the SME INVEST Program, through which loans for working capital or investments were granted to companies affected by the Covid-19 pandemic. Among the main facilities of the program are: the guarantee supported by the state, bearing interest, guarantee fees and financing costs (these deductions are incurred in the first phase in the first 8 months after the signing of the financing contract, with the possibility of extension) (National Credit Guarantee Fund for Small and Medium Enterprises, 2021).

4. Grants to SMEs affected by the COVID-19 pandemic, financial aid which is funded through the Competitiveness Operational Program 2014-2020, amounting to EUR 1 billion, namely (Ministry of European Investments and Projects, 2020):

a. Micro-grants: intended for PFAs (Authorized Natural Persons) and NGOs with economic activity in the cultural-artistic and cinematographic fields, individual medical offices involved in the treatment of COVID19 infected patients, with a value of 2,000 Euros.

b. Working capital grants amounting to EUR 350 million for SMEs in areas of activity such as: hospitality industry, transport services, events industry, publishing houses and libraries. (Maximum value of funding 150,000 Euros, set based on turnover).

c. Investment grants, intended for: SMEs in the food industry, energy, equipment, care services, repairs and maintenance, tourism, hotels, clothing, etc. Their value will be between 50,000 Euros and 200,000 Euros, depending on the financing needs of the investment projects submitted for contracting funds. 
In addition to these initiatives, a number of measures have been taken, such as: the possibility of postponing rates in case of inability to pay, deducting taxes, etc.

\section{Conclusions}

The main objective of the article was to conduct an analysis of the evolution of the concept of business continuity management, the contribution of implementing such a standard in organizations in the context of unfavorable situations, such as natural disasters, economic crises, pandemics, etc.

The main purpose is to identify from theory, practice or lessons learned the tools needed to ensure the long-term sustainability of the business and resilience in the event of a crisis.

One of the changes in practice in the context of the COVID-19 pandemic in response to the challenges was the implementation in the private sector of new forms of employment, in full swing at European level, but at a low level used by the Romanian labor market. Among these new forms of employment, the first to be distinguished is the work performed through information and communication technology, widely used in Romania, in situations where it is possible to carry out the activity from another location than the organization's headquarters.

The dynamics of changes in the labor market have been doubled by a number of protection measures, such as regulating technical unemployment or taking over the Kurzarbeit system, in which wage costs are shared between the state and the employer.

During the pandemic period, companies are also helped financially by the possibility to access grants from non-reimbursable funds for working capital or investments. The survival and continuity of the business for a large part of the Romanian business environment may depend on the efficiency of the management of these programs, which are still in full swing.

Thus, the resilience at the level of Romanian society is the result of a joint effort of the private and public environment, of efficient programming and effective implementation, of a new management, based on adaptability and flexibility, which will produce long-term changes in theory and practice generating knowledge and lessons learned for the future.

\section{REFERENCES}

Baba, H., Watanabe, T., Nagaishi, M., \& Matsumoto, H. (2014). Area Business Continuity Management, a New Opportunity for Building Economic Resilience, Procedia Economics and Finance, Vol. 18, 296-303. https://doi.org/10.1016/S2212-5671(14)00943-5.

Bakar, Z., Azbiya Yaacob, N.S., \& Udin, Z.M. (2015). Business Continuity Management Factors and Organizational Performance: A study on the Moderating Role of IT Capability. Journal of Management Info, Vol. 2, Issue 3, 5-12. DOI:10.31580/jmi.v7i1.38.

Bucoveţchi, O. (2013). System of Systems Approach Applied to Dynamic Business Processes Environment. International Conference of Management and Industrial Engineering, 469-474, WOS:000448492200057.

Bucoveţchi, O., Stanciu, R.D., \& Pulfer, R. (2017). Improvements in business towards system of systems engineering approach. Business \& Economics, Vol. 18, Suppl. 1, WOS:000417405000056.

Eurofound. (2015). New forms of employment. Luxembourg: Publications Office of the European Union.

Eurofound. (2020). New forms of employment: 2020 update, New forms of employment series. Luxembourg: Publications Office of the European Union. 
European Commission. (2020). State aid: Commission approves $€ 3.3$ billion Romanian scheme to support SMEs in coronavirus outbreak, available at: https://ec.europa.eu/ commission/presscorner/detail/ro/ip $20 \quad 649$, accessed 08 January 2021.

Herbane, B., Elliott, D., \& Swartz, E. (2004). Business Continuity Management: Time for a Strategic Role?. Long Range Planning (Long Range Plann), Vol. 37, Issue 5, 386-386, DOI:10.1016/j.1rp.2004.07.010.

Herfried, K. (2020). Standards for Management Systems, a Comprehensive Guide to Content, Implementation Tools, and Certification Schemes. Switzerland: Springer.

Järveläinen, J. (2020). Understanding the Stakeholder Roles in Business Continuity Management Practices - A Study in Public Sector. Hawaii International Conference on System Sciences, DOI: 10.24251/HICSS.2020.241.

Mandl, I., \& Curtarelli, M. (2017). Crowd Employment and ICT-Based Mobile Work New Employment Forms in Europe. In Meil, P., \& Kirov, V. (Eds), Policy Implications of Virtual Work. Switzerland: Palgrave Macmillan.

Marica, M. (2020). Employee sharing: a new type of employment, opportune in a globalized context. Proceedings of the International Conference on Business Excellence, Vol. 14, Issue 1, 1187-1195. DOI: https://doi.org/10.2478/picbe-2020-0111

Ministry of European Investments and Projects. (2020). State aid scheme to support SMEs affected by the COVID-19 pandemic approved by the European Commission, available at: $\quad$ https://mfe.gov.ro/schema-de-ajutor-de-stat-pentru-sprijinirea-imm-urilor-afectate-depandemia-covid-19-a-fost-aprobata-de-comisia-europeana/, accessed 08 January 2021.

National Credit Guarantee Fund for Small and Medium Enterprises. (2021). Available at: https://www.imminvest.ro/ accessed 08 January 2021.

Niemimaa, M., Järveläinen, J., Heikkilä, M., \& Heikkilä, J. (2019). Business Continuity of Business Models: Evaluating the Resilience of Business Models for Contingencies. International Journal of Information Management, Vol. $49 . \quad 208-216$. DOI:10.1016/j.ijinfomgt.2019.04.010.

Organisation for Economic Cooperation and Development (OECD). (2019). Roadmap: Platform-mediated workers, in Measuring the Digital Transformation: A Roadmap for the Future. Paris: OECD Publishing. https://doi.org/10.1787/f2873445-en.

Păunescu, C., Popescu, M.C., \& Blid, L. (2018). Business impact analysis for business continuity: Evidence from Romanian enterprises on critical functions. Management \& Marketing. Challenges for the Knowledge Society, Vol. 13, Issue. 3, 1035-1050, DOI: 10.2478/mmcks-2018-0021.

Şenturan, Ş. (2018). Interim Management Key Points for Success. Knowledge International Journal, Vol. 28, Issue 1, 69-72.

Theodore, N., Schenck, R., \& Blaauw, P.F. (2018). Casual Work, available at: https://www.researchgate.net/publication/327932860 Casual Work, accessed on 25 January 2021.

Zanfir, V. (2018). Comments on the legal regime of telework, available at: https://www.juridice.ro/587752/observatii-privind-regimul-juridic-al-telemuncii.html, accessed 08 January 2021. 